\title{
The use of recycled paper processing residues in making porous brick with reduced thermal conductivity
}

\author{
Mucahit Sutcu ${ }^{1}$, Sedat Akkurt* \\ Mechanical Engineering Department, Izmir Institute of Technology, 35430 Izmir, Turkey \\ Received 13 January 2009; received in revised form 26 January 2009; accepted 27 February 2009 \\ Available online 27 March 2009
}

\begin{abstract}
Production of porous and light-weight bricks with reduced thermal conductivity and acceptable compressive strength is accomplished. Paper processing residues were used as an additive to an earthenware brick to produce the pores. SEM-EDS, XRD, XRF and TG-DTA analysis of the paper waste and brick raw material were performed. Mixtures containing brick raw materials and the paper waste were prepared at different proportions (up to $30 \mathrm{wt} \%$ ). The granulated powder mixtures were compressed in a hydraulic press, and the green bodies were dried before firing at $1100{ }^{\circ} \mathrm{C}$. Dilatometric behaviours, drying and firing shrinkages were investigated as well as the loss on ignition, bulk density, apparent porosity, water absorption and thermal conductivity values of the fired samples. Their mechanical and microstructural properties were also investigated. The results obtained showed that the use of paper processing residues decreased the fired density of the bricks down to $1.28 \mathrm{~g} / \mathrm{cm}^{3}$. Compressive strengths of the brick samples produced in this study were higher than that required by the standards. Thermal conductivity of the porous brick produced in this study $(<0.4 \mathrm{~W} / \mathrm{m} \mathrm{K})$ showed more than $50 \%$ reduction compared to local brick of the same composition $(0.8 \mathrm{~W} / \mathrm{m} \mathrm{K})$. Conversion of this product to a perforated brick may reduce its thermal conductivity to very low values. Successful preliminary tests were conducted on an industrial scale.
\end{abstract}

(C) 2009 Elsevier Ltd and Techna Group S.r.l. All rights reserved.

Keywords: B. Porosity; C. Thermal conductivity; E. Structural applications; Brick; Paper waste

\section{Introduction}

Energy saving is an important issue in the world because of both economic and environmental concerns. Consumption of energy from buildings constitutes about $33 \%$ of total consumption with about half of this lost through the walls [1]. European standard EN832 states that, depending on the location and climate, walls should be made of material with a heat transfer coefficient of $0.4-0.7 \mathrm{~W} / \mathrm{m}^{2} \mathrm{~K}$, the lower the better [2]. If the thermal conductivity is further reduced heat loss will be decreased and, hence many brick manufacturers are seeking to produce such materials $[3,4]$. Earthenware clayey raw material is generally used with few pre-treatment steps for extruded perforated bricks. Firing temperature is generally of the order

\footnotetext{
* Corresponding author. Tel: +90 232750 6192; fax: +90 2327507890 .

E-mail addresses: mucahitsutcu@iyte.edu.tr (M. Sutcu), sedatakkurt@iyte.edu.tr (S. Akkurt).

${ }^{1}$ Tel.: +90 232750 6632; fax: +90 2327507890 .
}

of $1000{ }^{\circ} \mathrm{C}$. The product consists of vertical perforations to reduce heat transfer through the brick. There are two different thermal conductivity values of these bricks: first involves the bulk of the material constituting the walls while the second involves thermal conductivity of the entire product consisting of large vertical holes of rectangular cross-section. Bulk of the material has a thermal conductivity of roughly $0.8 \mathrm{~W} / \mathrm{m} \mathrm{K}$. This value can be reduced by addition of pore-forming agents to the brick before firing [5-11]. When this is made into an extruded product with vertical perforations its thermal conductivity will be much lower (e.g., as low as $0.08 \mathrm{~W} / \mathrm{m} \mathrm{K}$ ) [12-14]. Several different poreforming agents like wood sawdust, polymers, leather residues, mineral additives, polystyrene, coal dust, organic residues, paper-making sludge, and powdered limestone have been used [5-8,11].

There are different sources of paper residues suitable for use in bricks. Some researchers used residues obtained from primary paper mills to be incorporated into a brick [8]. In this study, however, residues from a recycled paper manufacturer are utilized in brick making. Chemistry of the residue is 
different from primary paper mills. In the recycled paper production, process involves a number of filtration steps to maintain the cellulose fiber as much as possible. The fraction that passes the final filter is regarded by the paper producers as waste and is hence stockpiled. This residue contains about $40 \%$ organic and $60 \%$ inorganic components like calcite and other clayey materials. In the paper industry, considerably high amount of residue is produced as a result of different mechanical, chemical and biological effluent treatment processes (for example; around 60 tons/day, in Levent Kagit Inc., Turkey). The amount and chemical composition of residues depend on the paper manufacturing process, raw materials used and the wastewater treatments applied. The quantity of residue generated corresponds to $50 \%$ of the paper production. The residues are generally either deposited or burnt. Disposal of this residue is an important environmental and economical problem for the paper industry. It has been proposed to convert this residue into an environmentally benign material by incorporating into a ceramic body $[5,8,11,19]$. Use of this residue for other purposes like a $\mathrm{pH}$-controlling substance [15], synthesis of calcium aluminosilicates with multifunctional sorption ability [16], pozzolanic addition in cement manufacturing [17], glass ceramics [18], light-weight, porous and high strength composite materials consisting of the mullite, cordierite and cristobalite phases [19] and as an organic pore-forming agent in bricks [8] is also reported.

The motivation behind this work which was inspired by the results of the above studies was the use of wastes in ceramic production where environmentally hazardous species would be used to produce a porous and light-weight ceramic body. Such a porous body can be used in making perforated bricks by extrusion to reduce thermal conductivity. Inorganic content of the residues used in this study was largely calcite with little more clay. This waste can form anorthite $\left(\mathrm{CaAl}_{2} \mathrm{Si}_{2} \mathrm{O}_{8}\right)$ or gehlenite $\left(\mathrm{Ca}_{2} \mathrm{Al}_{2}\right.$ $\mathrm{SiO}_{7}$ ) upon thermal treatment at higher than $1000{ }^{\circ} \mathrm{C}$. Pores are expected to form when cellulose fibers are burnt at $300-400{ }^{\circ} \mathrm{C}$. Below are given the procedure and results of tests to achieve a porous brick with improved thermal insulation properties.

\section{Experimental procedure}

\subsection{Materials and methods}

In this study, brick raw material obtained from a brick manufacturer (Yuksel Tugla) in Turgutlu, Turkey was used.
Paper processing residues were obtained from Levent Kagit Inc. They were initially subjected to pre-treatments such as drying and grinding. Particle size analysis of the brick raw material subjected to disc pulverizing was made on a Malvern Mastersizer-2000 Instrument to measure its particle size distribution. Chemical analysis of brick raw material and paper residues was made by using Energy Dispersive X-ray Fluorescence Spectrometer (XRF, Spectro IQ II). Then, they were characterized by X-Ray Diffractometer (XRD-Philips $\mathrm{X}$ 'Pert Pro) and thermo-gravimetric-differential thermal analysis (TG-DTA).

\subsection{Procedure for brick production}

Initially, brick raw material and paper processing residues were dried at $100{ }^{\circ} \mathrm{C}$ in oven. Then, they were powdered by a disc mill (Fritsch, Pulverisette 13). Dewatered residue was blended with industrially used ceramic powder in a Heidolph mixer at a mixing speed (650-800 rpm) for $30 \mathrm{~min}$. The resulting blends contained up to $30 \mathrm{wt} \%$ of wastes. The blends were dried in an oven at $110{ }^{\circ} \mathrm{C}$ for $16 \mathrm{~h}$. Dried blends were ground into mortar, and granulized with sprayed water $(10 \%$ moisture).

The granulated powder mixtures were uniaxially compacted in hydraulic press under a pressure of $10 \mathrm{MPa}$ for the rectangular-shaped specimens $(85 \mathrm{~mm} \times 85 \mathrm{~mm} \times 10 \mathrm{~mm})$. Pressing method was adopted in this study because these tests are laboratory tests. More industrial scale field trials were done using vacuum press to extrude perforated bricks with similar paper residue contents. The pressed specimens were held overnight at room temperature followed by drying at $45^{\circ} \mathrm{C}$ for $1 \mathrm{~h}$ in an oven. Dried specimens were fired in a laboratory-type electrical furnace at the rate of $2.5^{\circ} \mathrm{C} / \mathrm{min}$ until $600{ }^{\circ} \mathrm{C}$, and then at the rate of $10{ }^{\circ} \mathrm{C} / \mathrm{min}$ until $1100{ }^{\circ} \mathrm{C}$, for $1 \mathrm{~h}$. Fig. 1 shows the experimental flowchart. Changes in density and linear shrinkage values were measured using a caliper after drying and firing steps.

Also, Archimedes test was applied to fired samples. Their bulk density, apparent porosity and water absorption values were measured. Fired products were characterized for mechanical properties like compressive strengths, microstructures and mineral content. Thermal conductivity values of the bricks were measured by a Quick Thermal Conductivity Meter (QTM500, Kyoto Electronics). Samples were exposed to freeze-thaw test. Also, the sintering behaviour of the bricks was

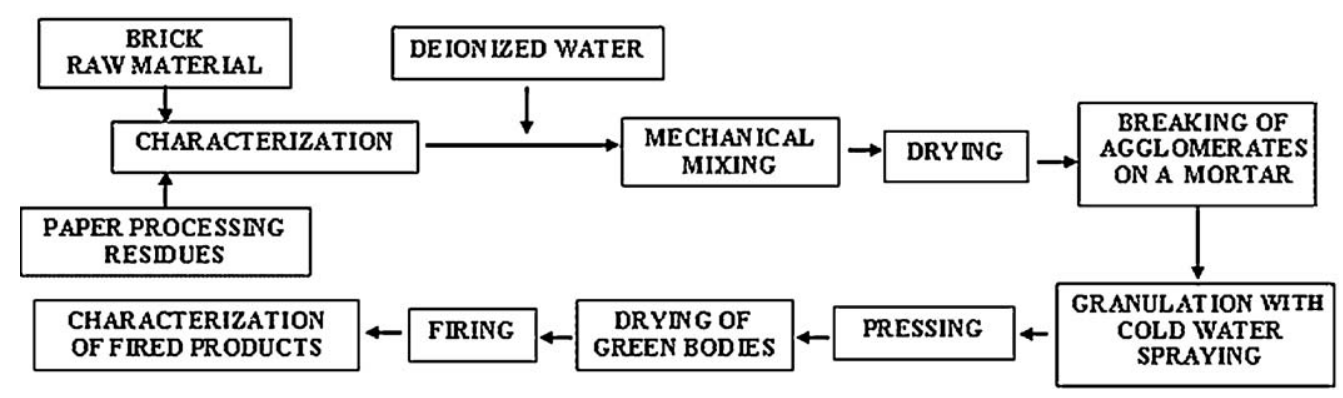

Fig. 1. Experimental flow chart for sample preparation. 


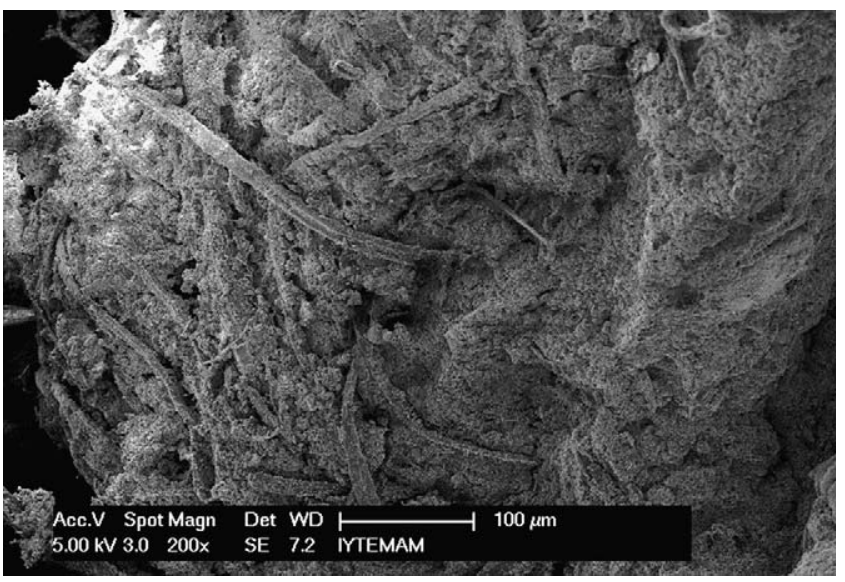

Fig. 2. The SEM image of paper processing residues.

investigated with a horizontal dilatometer (Linseis, Germany) using the same heating schedule as the other fired samples. Small sized pellets ( $8 \mathrm{~mm}$ diameter and $8 \mathrm{~mm}$ length) were used for dilatometric test.

\section{Results and discussion}

\subsection{Characterization of paper processing residues and brick raw material}

As-received paper processing residues obtained from the industry had about $65 \%$ moisture content. In Fig. 2, the SEM image of dried paper processing residues is shown. According to SEM-EDS analysis, these residues essentially consisted of cellulose fiber and $\mathrm{CaCO}_{3}$ along with some $\mathrm{SiO}_{2}, \mathrm{Al}_{2} \mathrm{O}_{3}$ and $\mathrm{MgO}$. Thicknesses of the fibers are between 5 and $20 \mu \mathrm{m}$. These residues were in the form of sludge which were dried in an oven at $100{ }^{\circ} \mathrm{C}$ before breaking of agglomerates.

Chemical analysis of the residues and brick raw material is given in Table 1 in oxide form. According to the XRF analysis, the residues included a large fraction of $\mathrm{Ca}$ in addition to $\mathrm{Si}, \mathrm{Al}$ and $\mathrm{Mg}$. This calcium most probably exists in the form of calcite $\left(\mathrm{CaCO}_{3}\right)$. Amount of the chlorine and sulfur $\left(\mathrm{SO}_{3}\right)$ was $0.17 \%$ and $0.09 \%$, respectively. Loss on ignition values of the residues and brick raw material upon heating at $1000{ }^{\circ} \mathrm{C}$ are $53.8 \%$ and $7.5 \%$, respectively. The amount of $\mathrm{Na}$ was too low to be included in Table 1 .

Eluate test analysis results of the refining paper sludge (TS EN 12457-4) made according to Turkish Hazardous Wastes

Table 1

Chemical analysis of brick raw material and waste.

\begin{tabular}{lcc}
\hline Compositions (wt \%) & Brick raw material & Paper processing residues \\
\hline $\mathrm{Al}_{2} \mathrm{O}_{3}$ & 15.71 & 4.14 \\
$\mathrm{SiO}_{2}$ & 61.65 & 6.42 \\
$\mathrm{CaO}$ & 2.16 & 32.91 \\
$\mathrm{MgO}$ & 2.30 & 1.54 \\
$\mathrm{~K}_{2} \mathrm{O}$ & 2.36 & 0.12 \\
$\mathrm{Fe}_{2} \mathrm{O}_{3}$ & 6.77 & 0.28 \\
$\mathrm{TiO}_{2}$ & 0.82 & 0.09 \\
$\mathrm{CuO}_{\mathrm{LOI}}$ & 0.26 & 0.25 \\
& 7.5 & 53.8 \\
\hline
\end{tabular}

Table 2

Eluate test analysis $(\mathrm{L} / \mathrm{S}=10 \mathrm{l} / \mathrm{kg}$ ) of the paper sludge $(\mathrm{mg} / \mathrm{l})$ [20].

\begin{tabular}{lll}
\hline Parameter & Measured & Standard \\
\hline $\mathrm{As}$ & $<0.1$ & $0.05-0.2$ \\
$\mathrm{Ba}$ & 0.108 & $02-10$ \\
$\mathrm{Cd}$ & $<0.01$ & $0.004-0.1$ \\
$\mathrm{Cr}$ & $<0.01$ & $0.05-1$ \\
$\mathrm{Cu}$ & 0.236 & $0.2-5$ \\
$\mathrm{Hg}$ & $<0.01$ & $0.001-0.02$ \\
$\mathrm{Mo}$ & $<0.1$ & $0.05-1$ \\
$\mathrm{Ni}$ & 0.113 & $0.04-1$ \\
$\mathrm{~Pb}$ & $<0.025$ & $0.05-1$ \\
$\mathrm{Sb}$ & $<0.02$ & $0.006-0.07$ \\
$\mathrm{Se}$ & $<0.02$ & $0.01-0.05$ \\
$\mathrm{Zn}$ & 0.21 & $0.4-5$ \\
$\mathrm{Cl}$ & 142 & $80-1,500$ \\
$\mathrm{~F}$ & 1.94 & $1-15$ \\
$\mathrm{SO}$ & 412 & $100-2,000$ \\
$\mathrm{DOC}$ & 74.3 & $50-80$ \\
$\mathrm{TDS}$ & 4000 & $400-6,000$ \\
$\mathrm{TOC}$ & $48470 \mathrm{mg} / \mathrm{kg}$ & $50,000 \mathrm{mg} / \mathrm{kg}$ \\
$\mathrm{H}$ & &
\end{tabular}

DOC: decomposed organic carbon; TDS: total decomposed solid; TOC: total organic carbon.

Regulation (EK11A) are given in Table 2. According to this analysis results, these residues do not represent a major threat for the environment in regard to heavy metal content, thus they could be classified as a non-hazardous waste [20].

The crystallinity and phase analyses of the residue and brick raw material were investigated by using XRD with $\mathrm{CuK}_{\alpha}$ radiation $(\lambda=1.542 \AA)$ at $40 \mathrm{kV}$ in the $2 \theta$ intervals of $5-100^{\circ}$. Fig. $3 a$ and $b$ shows XRD patterns of the paper processing residues and brick raw material, respectively. XRD analysis showed that the residues contained calcite and a weak peak for cellulose was observed. Brick raw material includes quartz, muscovite/illite, clinochlore and some calcite.

Particle size distribution of the brick raw material is as shown in Fig. 4. Average particle size was $16 \mu \mathrm{m}$.

\subsubsection{Thermal behaviour of raw materials}

Thermal analysis of paper processing residues was carried out by using Shimadzu TGA-51/51H for TGA type of instrument. Approximately $11.5 \mathrm{mg}$ sample was heated at $10{ }^{\circ} \mathrm{C} / \mathrm{min}$ under $40 \mathrm{ml} / \mathrm{min}$ nitrogen purge stream up to $1000{ }^{\circ} \mathrm{C}$. Fig. 5a and b shows the TG-DTA curves of paper processing residues and brick raw material, respectively. As can be seen from Fig. 5a, for paper processing residues, total weight loss of about $53.8 \%$ was observed at $1000{ }^{\circ} \mathrm{C}$. The first $4 \%$ decrease in the mass occurred in between 25 and $200{ }^{\circ} \mathrm{C}$ due to the evaporation of physical water. The second mass loss (28.5\%) was observed in the $280-500{ }^{\circ} \mathrm{C}$ range which may be largely due to the burning of paper residues. The weight loss (21\%) observed above $700{ }^{\circ} \mathrm{C}$ may be due to the decomposition of carbonates. In DTA curve, there was mainly one large exothermic reaction between 300 and $500{ }^{\circ} \mathrm{C}$ corresponding to the burning of cellulose in paper residues. Another reaction was observed around $700{ }^{\circ} \mathrm{C}$ which corresponds to the decomposition of calcium carbonate. The former exotherm can be considered useful as a contribution to thermal content of the 

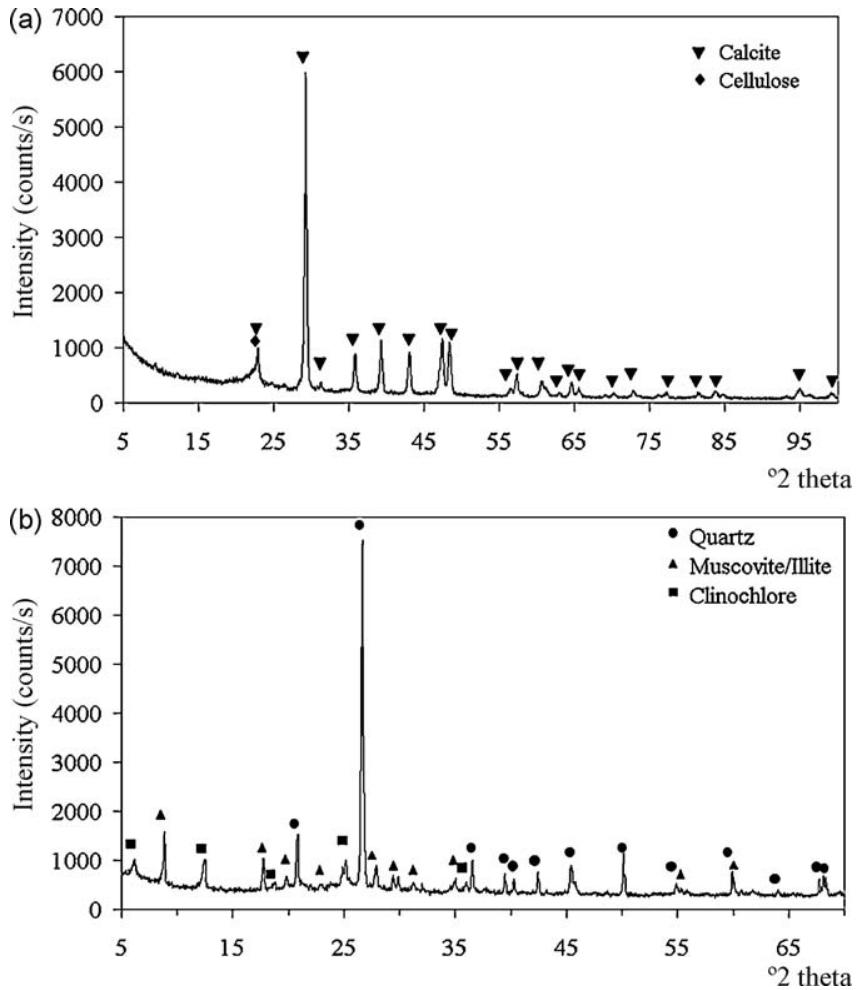

Fig. 3. X-ray diffraction patterns of: (a) paper processing residues and (b) asreceived brick raw material.

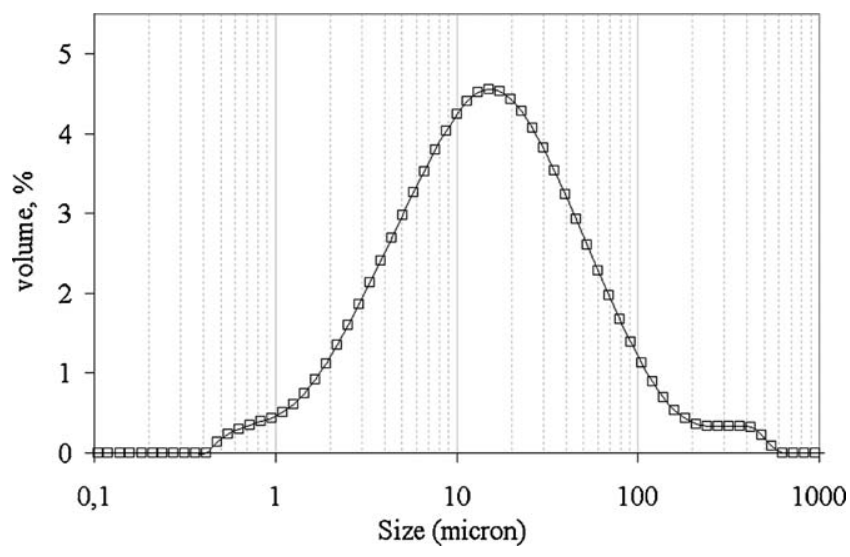

Fig. 4. Particle size distribution of brick raw material as measured by laser scattering (Malvern Mastersizer).

kiln on firing of the brick that contains paper residue. The latter calcite decomposition peak is more a liability than an asset for thermal load.

In Fig. 5b TG/dTGA curves of brick raw material are given. Total weight loss of about $6 \%$ was observed at $1000{ }^{\circ} \mathrm{C}$. The first $1.5 \%$ decrease in the mass occurred in between 50 and $100{ }^{\circ} \mathrm{C}$ due to the evaporation of physical water. The second $(0.5 \%)$ and third $(1.5 \%)$ weight losses were observed between 200-300 and $350-500{ }^{\circ} \mathrm{C}$ ranges which may be due to the burning of organic matter and the removal of chemical water [21]. The larger weight loss (2\%) was detected in between 500 and $700{ }^{\circ} \mathrm{C}$ range and smaller reaction at about $850-900{ }^{\circ} \mathrm{C}$
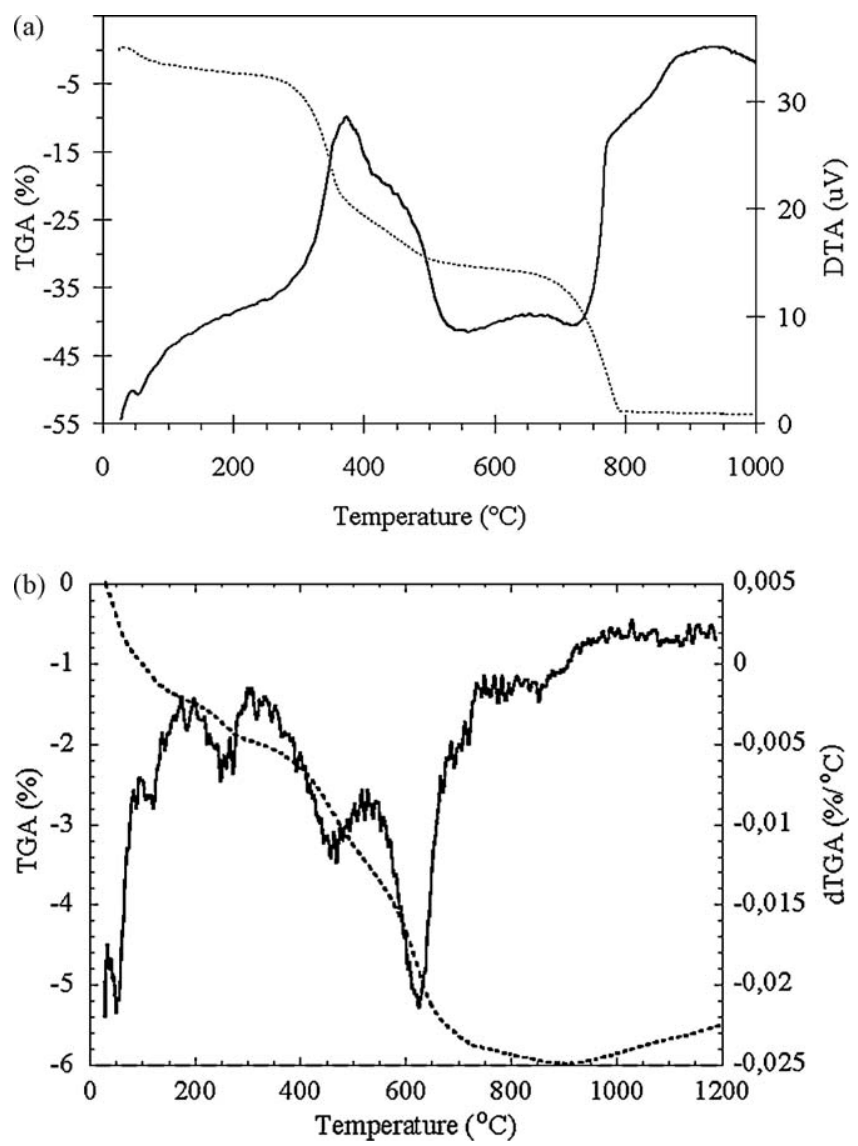

Fig. 5. TG-DTA curves of: (a) paper processing residues and (b) brick raw material in nitrogen atmosphere.

which is related with the dehydroxylation of illite and clinochlore mineral [22].

\subsection{Characterization of the fired products}

\subsubsection{Dilatometric analysis of the pellets}

Thermal dilatometric analysis was performed on unfired samples. Note that the irreversible trace goes through all of the expansions and contractions that will typically occur during first firing of samples. Fig. 6a and $\mathrm{b}$ shows linear shrinkage and shrinkage rate $\left({ }^{\circ} \mathrm{C}^{-1}\right)$ curves during firing to $1100{ }^{\circ} \mathrm{C}$ of the samples with or without additives. The only significant shrinkage occurs at about $100{ }^{\circ} \mathrm{C}$ during drying and this accounts for only about $0.2-0.5 \%$ of shrinkage for samples containing up to $30 \%$ waste. The expansion between 530 and $585{ }^{\circ} \mathrm{C}$ in all samples is observed to be about $0.4 \%$ due to the transformation of quartz. After about $800{ }^{\circ} \mathrm{C}$, shrinkage of samples with residues is delayed compared to the sample without the residue due possibly to decomposition of calcite. Finally, while the sample without residue shrinks about $3 \%$, the samples with $10 \%, 20 \%$ and $30 \%$ residue shrink by $2 \%, 1.9 \%$ and $1 \%$, respectively.

\subsubsection{Test results of the bricks}

Up to this point, paper residue additions of as much as $30 \mathrm{wt} \%$ were done in making fired brick. It was observed that 

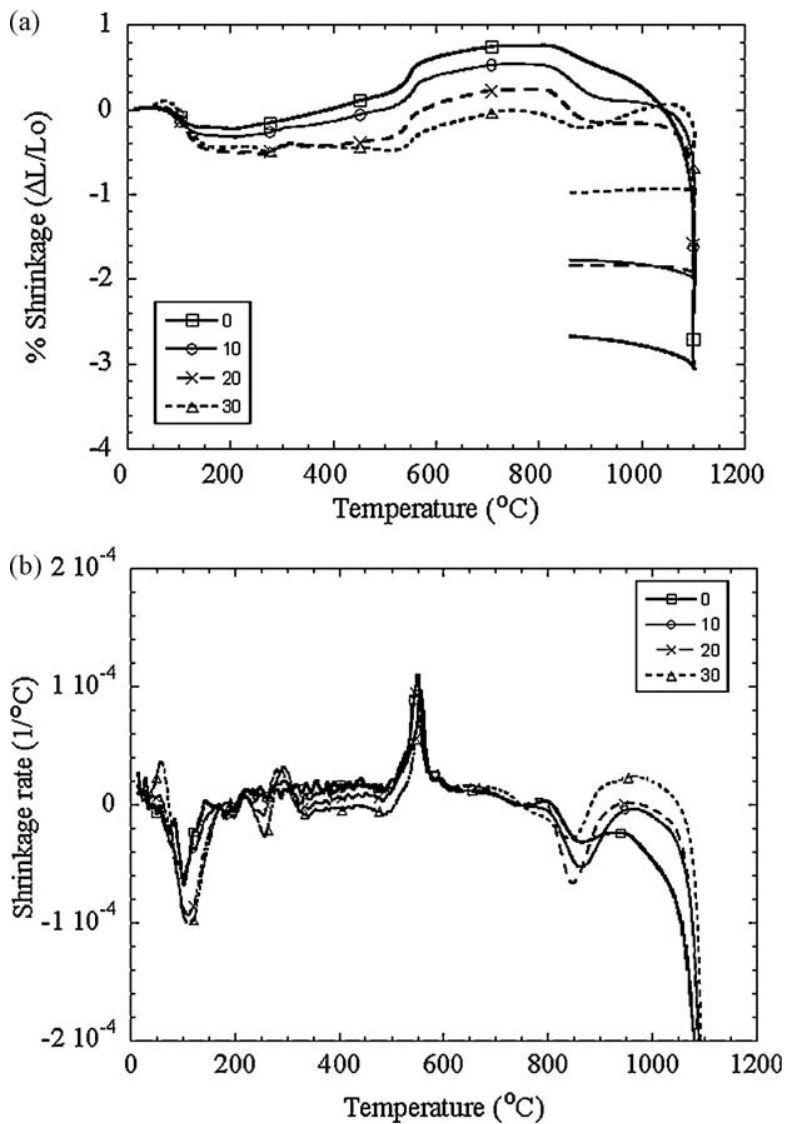

Fig. 6. (a) Linear shrinkage and (b) shrinkage rate $\left({ }^{\circ} \mathrm{C}^{-1}\right)$ curves of the samples.

the color of the brick got lighter shades of red with increasing amount of residue additions due to the presence of higher amounts of calcium. Experimental results of the samples fired at $1100{ }^{\circ} \mathrm{C}$ are given in Table 3 . Dimension and volume of the samples were measured by a caliper, and their green, dry and fired densities were calculated. Also, bulk densities, apparent porosity and water absorption values were measured by using boiling water absorption via the Archimedes method. The results obtained revealed that green, dry, fired and bulk densities decreased steadily with an increase in the amount of the residues.

The changes in density and loss on ignition values observed for bricks with respect to residue content are shown in Table 3. Their drying shrinkage values varied between $1 \%$ and $2 \%$. Fired density of the bricks decreased from 1.92 to $1.28 \mathrm{~g} / \mathrm{cm}^{3}$, which corresponds to a decrease by $33 \%$ compared to density of the brick without residues.

Archimedes test results of the samples taken from fired bricks are given in Table 3. The volumes of tested samples were $1 \mathrm{~cm}^{3}$. Apparent porosity and water absorption values were increased with increase in waste addition while the bulk densities were significantly reduced. Lowest bulk density achieved so far is $1.28 \mathrm{~g} / \mathrm{cm}^{3}$.

Compressive strengths of the fired brick samples as measured in different sample orientations are listed in Table 3. Shaping (pressing) direction of the brick and the shape of the pores affect the mechanical strength. Depending on the increase in the residue addition and porosity content, compressive strength of the samples decreased. Compressive strengths of the samples were still higher than the standard strength values. According to Turkish and corresponding European Standards (TS EN 771-1), the minimum strength for building bricks is $7 \mathrm{MPa}$ [23]. The compressive strength for severe weathering ( $\mathrm{SW}$ ) brick is $20 \mathrm{MPa}$ [24]. In our study, strengths of samples with $0 \%$ and $10 \%$ residue were higher than that of SW brick.

The relation between thermal conductivity and apparent porosity of the bricks with residue addition can be observed in Table 3 . The thermal conductivity values indicated a decrease of up to $50 \%$ which is encouraging for higher energy saving potential in residential applications. It can clearly be seen that thermal conductivities of the bricks are closely related with their densities and porosities.

Table 3

Measured values of the bricks fired at $1100{ }^{\circ} \mathrm{C}$.

\begin{tabular}{|c|c|c|c|c|}
\hline \multirow[t]{2}{*}{ Properties } & \multicolumn{4}{|c|}{ Percent paper residue additions by weight } \\
\hline & $0 \%$ & $10 \%$ & $20 \%$ & $30 \%$ \\
\hline \multicolumn{5}{|l|}{ As measured by a caliper } \\
\hline Green density $\left(\mathrm{g} / \mathrm{cm}^{3}\right)$ & 2.16 & 2.03 & 1.96 & 1.83 \\
\hline Dry density $\left(\mathrm{g} / \mathrm{cm}^{3}\right)$ & 2.03 & 1.88 & 1.80 & 1.64 \\
\hline Fired density $\left(\mathrm{g} / \mathrm{cm}^{3}\right)$ & 1.92 & 1.65 & 1.49 & 1.28 \\
\hline Loss on ignition (\%) & 7.5 & 12.3 & 17.0 & 22.0 \\
\hline \multicolumn{5}{|l|}{ As measured by Archimedes test } \\
\hline Apparent porosity (\%) & 30.8 & 38.9 & 46.2 & 52.0 \\
\hline Water absorption $(\%)$ & 16.7 & 23.9 & 31.9 & 40.4 \\
\hline Apparent specific gravity $\left(\mathrm{g} / \mathrm{cm}^{3}\right)$ & 2.68 & 2.65 & 2.69 & 2.69 \\
\hline Bulk density $\left(\mathrm{g} / \mathrm{cm}^{3}\right)$ & 1.85 & 1.62 & 1.45 & 1.29 \\
\hline \multicolumn{5}{|l|}{ Compressive strengths, $\left(\mathrm{kg} / \mathrm{cm}^{2}\right)$} \\
\hline At pressing direction & $400 \pm 200$ & $160 \pm 20$ & $76 \pm 9$ & $51 \pm 1$ \\
\hline At transverse direction & $450 \pm 150$ & $235 \pm 15$ & $150 \pm 10$ & $74 \pm 1$ \\
\hline Thermal conductivity (W/m K) & $0.83 \pm 0.03$ & $0.59 \pm 0.03$ & $0.48 \pm 0.01$ & $0.42 \pm 0.02$ \\
\hline
\end{tabular}




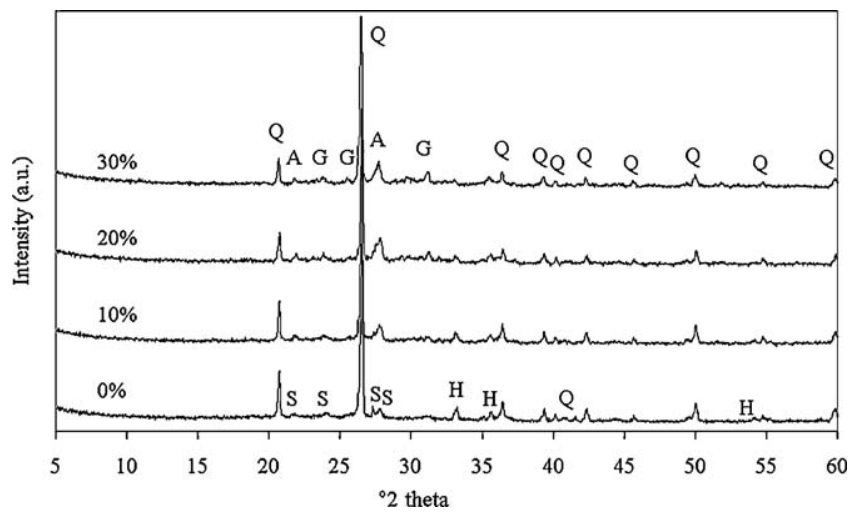

Fig. 7. XRD results of fired bricks (Q: quartz; H: hematite; S: sanidine; A: anorthite; G: gehlenite).

The bricks were subjected to freeze-thaw performance tests. Saturated bricks were placed in a pan of water. And then, they were placed in a freezer. The bricks were frozen for $12 \mathrm{~h}$ and then thawed and exposed to the sun. Again they were allowed to refreeze for two cycles per day. Finally, failure and cracking on the bricks were not observed after three cycles. This quick test is not sufficient to classify the bricks as frost resistant as many more cycles need to be repeated.

In this study, forming technique of bricks was pressing which gave good results in both structural, thermal and
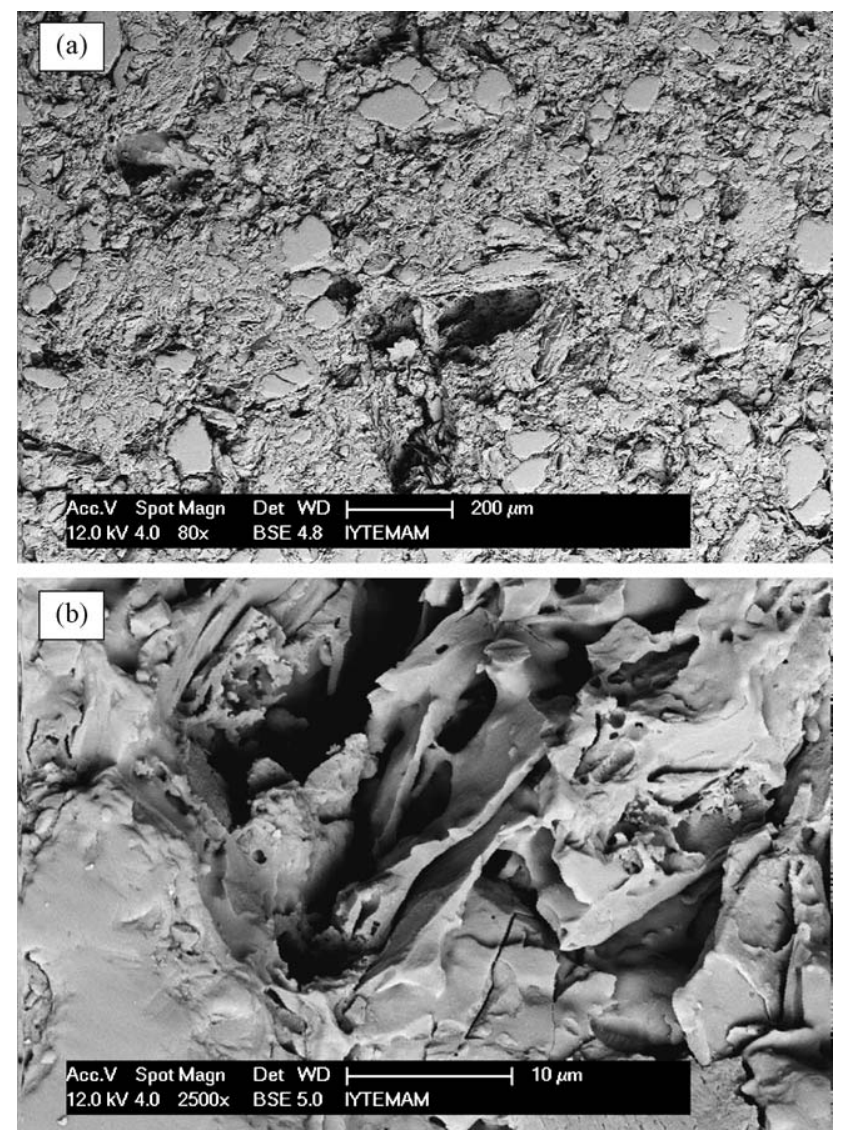

Fig. 8. The SEM images of fired bricks without residue, at various magnifications.
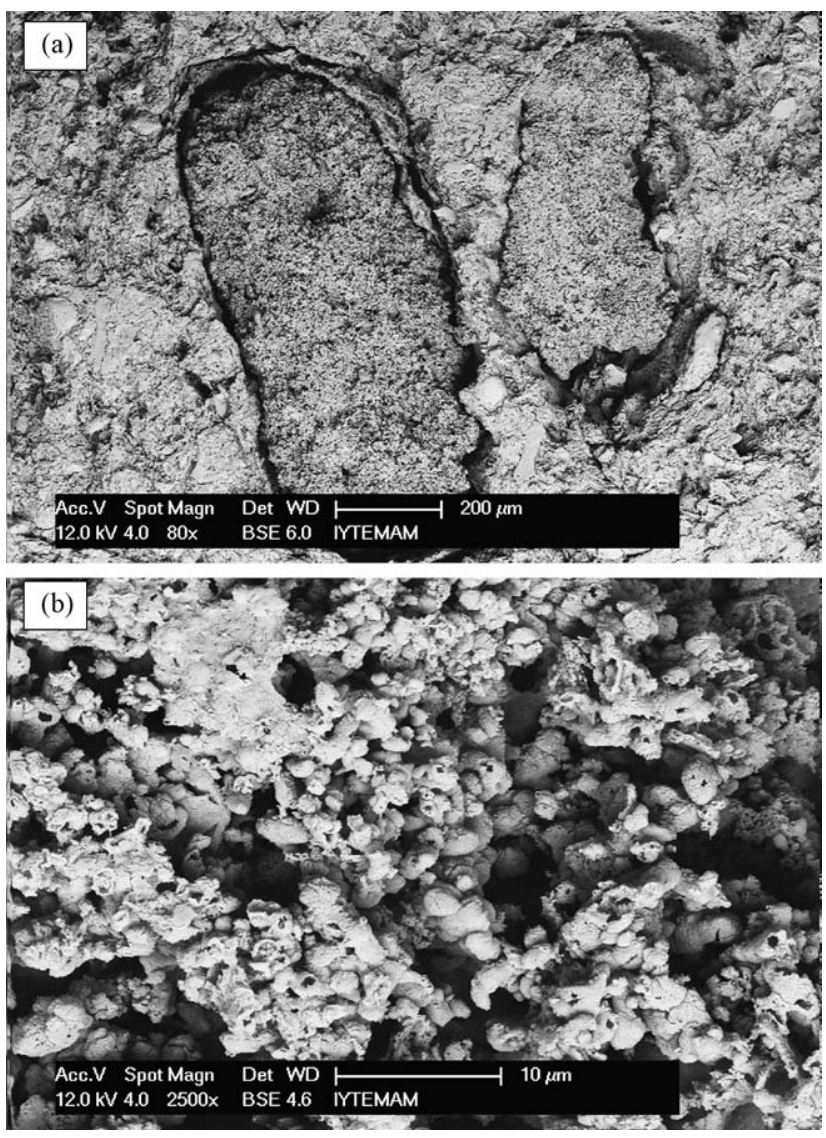

Fig. 9. The SEM images of fired bricks with $30 \%$ residue, at various magnifications: (a) body with $\mathrm{CaO}$-rich grains and (b) $\mathrm{CaO}$-rich porous structure in brick with $30 \%$ residue.

mechanical properties of the products on small laboratory sized samples. An industrial partner helped run industrial scale trials by extrusion technique which proved successful. In these runs paper residues of as much as $20 \%$ were added together with a total water content of $18 \%$ to produce perforated bricks of improved thermal properties. An addition of $20 \%$ by volume of residue to brick raw material successfully produced a brick of $8 \%$ loss on ignition value with sufficient mechanical strength. Significant reductions in thermal conductivities are achieved in these products. Industrial scale tests are in progress.

\subsubsection{Microstructural and phase analysis of the bricks}

Fig. 7 shows XRD patterns of fired bricks. XRD analysis obviously shows that non-additive brick consists of quartz $\left(\mathrm{SiO}_{2}\right)$ on a large scale, and also hematite $\left(\mathrm{Fe}_{2} \mathrm{O}_{3}\right)$ and sanidine $\left(\mathrm{KAlSi}_{3} \mathrm{O}_{8}\right)$. Paper residue containing-bricks consist mainly of quartz and hematite as well as anorthite $\left(\mathrm{CaAl}_{2} \mathrm{Si}_{2} \mathrm{O}_{8}\right)$ and gehlenite $\left(\mathrm{Ca}_{2} \mathrm{Al}_{2} \mathrm{SiO}_{7}\right)$. As addition of paper residues increased, amount of anorthite and gehlenite phases increased.

Figs. 8 and 9 illustrate the SEM images of fired bricks with $0 \%$ and $30 \%$ residue, respectively. Fig. $8 \mathrm{~b}$ shows local vitrification in the brick. Brick with $30 \%$ residue has larger pores due to the burning of organic matter. Calcite rich particles in the brick also contributed to a less extent to the formation of the porous structure upon thermal treatment due to the loss of 
$\mathrm{CO}_{2}$. These $\mathrm{CaO}$-rich particles in brick had a porous structure as shown in Fig. 9. Chemistry of these particles of roughly 200 $1000 \mu \mathrm{m}$ were largely composed of calcium with less $\mathrm{Si}, \mathrm{Fe}$, $\mathrm{Al}$, and Mg. Fig. $9 \mathrm{~b}$ shows in closer view the fine network of highly porous structure which is extremely helpful in reducing thermal conductivity of the brick by resisting convective heat transport. Movement of air is restricted in this case as opposed to be a completely vacant closed pore in which heat transfer would be freely carried out by air molecules.

\section{Conclusions}

Incorporation of industrial paper production residues into a ceramic product is accomplished. Results indicated that little shrinkage (1-2\%) occurred in the brick that contained residue while the brick without residue shrunk by about $3 \%$. Their fired densities varied between 1.92 and $1.28 \mathrm{~g} / \mathrm{cm}^{3}$, which correspond to a decrease of $33 \%$ compared to the density of the brick without residue. Apparent porosity and water absorption values were increased with increase in residue addition. Pressing direction of the bricks and shape of the pores in samples have a considerable effect on mechanical strength. Depending on the increase in the residue addition and porosity content, compressive strength of the samples decreased. Compressive strength of the samples was still higher than the standard strength values. Their thermal conductivity values decreased by up to $50 \%$ while adequate mechanical strength could be maintained. Results indicated that the residues could be easily utilized as pore-forming additives into brick bodies to facilitate production of vertically perforated insulation bricks. Preliminary results on an industrial scale indicated successful production of paper residue containing insulation bricks with reduced thermal conductivities.

\section{Acknowledgements}

The author would like to thank Levent Kagit A.S. for providing the paper residues and to Yuksel Tugla A.S. for the brick raw materials and industrial scale tests. Thanks are also due to Dr. Birol Uner for discussion on paper residues and to the Geothermal Energy Research and Application Center for their helps in thermal conductivity measurements.

\section{References}

[1] P. Wouter, Energy Performance of Building: Assessment of Innovative Technologies, ENPER-TEBUC, Final Report, 2004.
[2] EN 832:1998-Thermal Performance of Buildings-Calculation of Energy Use for Heating-Residential Buildings, CEN, Brussels, Belgium, 1998.

[3] WEB_1, 2008, http://www.wienerberger.de.

[4] WEB_2, 2008, http://www.rimmele.de.

[5] M. Dondi, M. Marsigli, B. Fabbri, Recycling of industrial and urban wastes in brick production, Tile and Brick International 13 (3) (1997) 218 225.

[6] K. Junge, Additives in the brick and tile industry, Zi Brick and Tile Industry International 53 (12) (2000) 25-39.

[7] R. Köhler, Use of leather residues as pore-forming agents for masonry bricks, Ziegelindustrie International 58 (3) (2002) 30-38.

[8] I. Demir, M.S. Baspınar, M. Orhan, Utilization of kraft pulp production residues in clay brick production, Building and Environment 40 (2005) 1533-1537.

[9] E. Rimpel, Industrial production of high-porosity brick materials, Ziegelindustrie International Annual (1996) 174-207.

[10] M. Swoda, Improvement of production and product characteristics with vupper, Ziegelindustrie International (March) (1997) 100-106.

[11] V. Ducman, T. Kopar, The influence of different waste additions to clayproduct mixtures, Materials and Technology 41 (6) (2007) 289-293.

[12] E. Rimpel, F. Rehme, Development of extruded, high thermal insulating bricks, Ziegelindustrie International 57 (12) (2001) 36-41.

[13] A. Erker, F. Heyder, The influence of the cross sectional design of vertically perforated clay masonry units on thermal insulating requirements, Ziegelindustrie International 49 (2) (1996) 123-131.

[14] WEB_3, 2008, http://www.fbt.ie/poroton.html.

[15] M.R. Boni, L. D'Aprile, G. De Casa, Environmental quality of primary paper sludge, Journal of Hazardous Materials B 108 (2004) 125-128.

[16] V.K. Jha, Y. Kameshima, A. Nakajima, K. Okada, J.D. MacKenzie, Multi functional behaviour of materials prepared by calcining waste paper sludge, Journal of Environmental Science and Health Part A 41 (2006) 703-719.

[17] R. Garcia, R.V. Villa, I. Vegas, M. Firas, M.I.S. Rojas, The puzzolanic properties of paper sludge waste, Construction and Building Materials 22 (July (7)) (2008) 1484-1490.

[18] T. Toya, Y. Kameshima, A. Nakajima, K. Okada, Preparation and properties of glass-ceramics from kaolin clay refining waste (Kira) and paper sludge ash, Ceramics International 32 (2006) 789-796.

[19] S. Dasgupta, S.K. Das, Paper pulp waste-A new source of raw material for the synthesis of a porous ceramic composite, Bulletin of Material Science 25 (October (5)) (2002) 381-385.

[20] Dokuz Eylül University, Department of Environmental Engineering, Analysis Report, March 9, 2006.

[21] C.M.F. Vieira, R. Sánchez, S.N. Monteiro, Characteristics of clays and properties of building ceramics in the state of Rio de Janeiro, Brazil, Construction and Building Materials 22 (2008) 781-787.

[22] D.A. Brosnan, What's Happening During Preheat?-Part II: Decomposition of clay crystals and quartz inversions, Brickyard Road - the Magazine of the Clemson Brick Forum and the National Brick Research Center, January, (2002), pp. 21-24.

[23] Turkish Standard Institution (TS EN 771-1), Specification for Masonry Units-Part 1: Clay Masonry Units, 2005.

[24] J.E. Alleman, Beneficial Use of Sludge in Building Components, National Science Foundation Grant No. ISP-8021357, December 1983. 